\title{
The Impact Of Innovation and Information Technology At Government Synergy Program On Micro, Small, Medium Entreprises (MSMES) Development In North Sumatra
}

\author{
Beby Karina Fawzeea \\ Department of Management \\ Universitas Sumatera Utara \\ Medan, Indonesia \\ bebykarina2017@yahoo.com \\ Fivi Rahmatus Sofiyah \\ Department of Management \\ Universitas Sumatera Utara \\ Medan, Indonesia
}

\author{
Ami Dilham \\ Department of Management \\ Universitas Sumatera Utara \\ Medan, Indonesia \\ Ilyda Sudardjat \\ Department of Management \\ Universitas Sumatera Utara \\ Medan, Indonesia
}

\begin{abstract}
The purpose of this research is to know the impact of innovation and information technology at government synergy program On MSMES Development In North Sumatra. This Research is descriptively quantitative with the area focus such as: Medan, Binjai, Sibolga, Padang Sidempuan, Tebing Tinggi, Tanjung Balai, Siantar, Asahan, Deli Serdang and Tanah Karo as many as 300 respondents by using purposive sampling technique. Primary data collection is used through questionnaires, interview, observation, and documentation as well. as the secondary data is got from library research, text book, government institution, and journal review. Multiple correlation regression and path analyze are used to see the influence with SPSS 16 instrument research. The result of the research is the positive and significant influence on innovation and information technology (IT) at government synergy program on MSMEs Development in North Sumatra.
\end{abstract}

Keywords—synergy; technology; innovation; IT; MSMEs

\section{INTRODUCTION}

Globalization and the free market are challenges for MSMEs. The advances in IT make the business actor have to follow it. The Increasing advanced technology and free competition have increased customer awareness of the wide selection of products and services have to be chosen. If MSMEs as entrepreneurs do not immediately fix themselves, the business actors will be threatened to lose competition Asean Economic Competition (AEC) so that they need to fix from the readiness of IT and innovation to survive and develop.

The empowerment of MSMEs in the midst of globalization and high competition make MSMEs have to be able to face global challenges such as improving product and service innovation, human resource and technology development, and expansion of marketing area. It needs to be done to increase the selling value of MSMEs itself, especially in order to compete with foreign products that are increasingly happened in manufacturing centers in Indonesia for economic sector that is able to absorb the largest workforce in Indonesia [1].

Most of 99\% MSMEs in Indonesia are micro enterprises in the informal sector and generally use local raw materials with local markets. It is not directly affected by the global crisis. The World Economic Forum (WEF) 2010 report places the Indonesian market at the $15^{\text {th }}$ rank. It shows that Indonesia as a potential market for other countries. This potential has not been utilized by UMKM maximally (World Economic Forum [2].

Without innovation, the majority of MSMEs will not be able to accommodate the structural changes occurring in their economic environment. To improve its competitiveness, MSMEs must innovate continuously. To determine the effect of innovation on the development of SMEs, a measurement should be done. In the measurement of innovation, the elements to be considered are innovation culture and capacity [3].

Innovation is taking place everywhere through new and emerging technologies changing the way we think, live, breathe, travel, and do shopping to name a few areas. Funny enough is that some of us believe that the most important technologies are on the market available to please customers and users, and nothing more important will show up later [4].

The process of innovation, however, can be closed or open, or semi-closed or semi-open, depending on the strategy of the company. The view of innovation strongly based on R\&D and the absolute need to develop internal capacity to integrate external R\&D is also open to criticism [5].

Both researchers and practitioners in the field of communication have already indicated that in the $20^{\text {th }}$ century, an organization's internal communication determines how efficient, successful and performance-orientated it is. Yet this 
position on internal communication quite often is related to such notions as "employee information", "raising the efficiency of employees" and "one-way communication" [6].

The ability to quantify this value was limited for decades to direct monetary values (profit increases or cost reductions) and those related to $R \& D$ ( $R \& D$ expenditures, $R \& D$ assets, patents, copyrights, etc.). While the limitations of these metrics were well known, there were limited alternatives [7].

The product launch and presentation to the market is a crucial moment of the whole development process. This is an important phase to reach success in sales. Different communications activities are planned: press releases, brochures, videos, interviews, and participation in trade fairs. The choice depends on the kind of commodity and on the target market in which to effectively promote the product [8].

Products equilibrium illustrates a problem, every product exists in the market always has its own value. Through helping customer to analysis and modify orders, client manager makes this orders reflect the demand of the market more accurately so that the products can be sale equilibrium [9].

Internet advertising started in 1994 in the form of banner advertisement. Banners are most popular as Internet advertising tool, compared to pop-up-windows, interstitials. During that time, Internet becomes mainly used for company's marketing communication. That's why banners were integrated into the company's websites [10].

Like other advertising media, online advertising frequently involves both a publisher, who integrates advertisements into its online content and an advertiser who provides the advertisements to be displayed on the publisher's content. Other potential participants include advertising agencies that help generate and place the advertisement copy, the advertisement server who technologically delivers the advertisement and tracks statistics and advertising affiliates who do independent promotional work for the advertiser [11].

\section{RESEARCH METHODOLOGY}

The technique used in the research samples is purposive sampling that is sampling research based on certain criteria. Research sample of 300 respondents who focus on MSMEs located in: Medan, Binjai, Sibolga, Padang Sidimpuan, Tebing Tinggi, Tanjung Balai, Siantar, Asahan, Deli Serdang and Karo.

Primary data collection is used by distributing questionnaires and conducting interviews to respondents while secondary data is used by literature study, scientific journals and website. The analysis method used is Multiple Linear Regression to measure the relationship between two or more variables, also shows the direction of the relationship between the dependent variable with independent variables and Path Analysis used to see the effect of independent variables on dependent variable directly or indirectly.

\section{RESULTS AND DISCUSSION}

\section{A.Classic Assumption Test}

\section{1) Normality test}

Normality test in this research is done by using one sample Kolmogorov-Smirnov test because the result of this test is more relevant than doing the test graph. Table 1 shows that the value of Asymp. Sig. (2-tailed) of 0.312 is greater than 0.05 . So it can be concluded that the data tested in this study is normally distributed.

Table 1 . Normality Test Results

\begin{tabular}{|llr|}
\hline & & $\begin{array}{c}\text { Unstandardized } \\
\text { Residual }\end{array}$ \\
\hline N & Mean & 300 \\
& Std. Deviation & 0 \\
Most Extreme & Absolute & 1.36123317 \\
Differences & Positive & 0.056 \\
& Negative & 0.056 \\
Kolmogorov-Smirnov Z & & -0.04 \\
Asymp. Sig. (2-tailed) & & 0.963 \\
\end{tabular}

\section{2) Heteroscedasticity Test Results}

This test aims to test whether in the regression model there is an inequality of variance from the residual one observation to another one. From the Fig. 1 of heteroscedasticity test output can be seen that there is no clear pattern as well as no dot points, and spots spread and below the number 0 on the $\mathrm{Y}$ axis, it can be concluded that there is no heteroscedasticity.

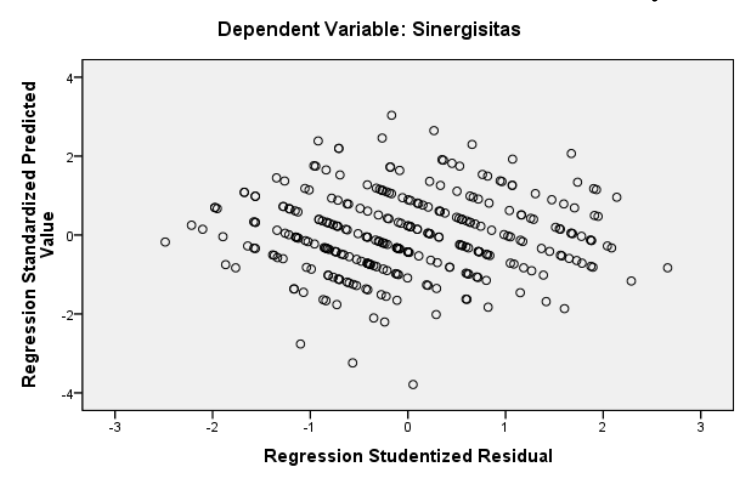

Fig. 1. Heteroscedasticity Test Results

\section{Multicollinearity Test Results}

This test aims to test whether the regression model found a correlation between independent variables. A good regression model should not be correlated between independent variables. The provision in multicollinearity test, If the Tolerance value $>$ 0.10 and $\mathrm{VIF}<10$, then it can be interpreted that there is no multicollinearity in the study. From Table 2, it is concluded 
that there are no symptoms of multicollinearity in the interaction of innovation, information technology as well as MSMEs variables as each tolerance value is above 0.10 and also the VIF value is below 10 .

\begin{tabular}{|l|r|r|}
\hline \multicolumn{2}{|c|}{ Table 2. Multicollinearity Test results } \\
\hline & Tolerance & \multicolumn{1}{c|}{ VIF } \\
\hline (Constant) & & \\
Innovation & 0.768 & 1.302 \\
IT & 0.796 & 1.256 \\
MSMEs & 0.67 & 1.429 \\
\hline
\end{tabular}

\section{A. Multiple Linear Regression Analysis Model I Results}

In this study, multiple linear regression analysis is used to test the hypothesis. Based on these results can be formed equation I as follows :

$$
\mathrm{Y}=11.847+0.308+0.244+\mathrm{e}
$$

Based on the model can be interpreted:

1) Constant (a) of 11.847 indicates the value of the variable of MSMEs development will remain at 11.847 if all independent variables are zero.

2) Innovation has a coefficient value of 0.308 , means that if the value of this variable is increased one unit then it will increase the value of the variable development of MSMES by $0.308(30.8 \%)$ with the assumption that other variables are fixed.

3) Information technology has a coefficient value of 0.244 , means that if the value of this variable is increased one unit, it will increase the value of the variable development of smes by $0.244(24.4 \%)$ assuming other variables are fixed value.

Table 3. Results of Multiple Linear Regression Analysis Equation Model I

\begin{tabular}{lrll}
\hline \multicolumn{1}{r}{ Model } & \multicolumn{1}{c}{$\mathrm{B}$} & $\mathrm{t}$ & \multicolumn{1}{c}{ Sig } \\
\hline (Constant) & 11.847 & 8.445 & .000 \\
Innovation & .308 & 7.662 & .000 \\
IT & .244 & 6.801 & .000 \\
\hline
\end{tabular}

\section{B. Multiple Linear Regression Analysis Model II Results}

Based on these results can be formed equation II as follows

$$
\mathrm{Y}=3.713+0.152+0.133+0.564+\mathrm{e}
$$

Based on the model can be interpreted:

- The constant (a) of 3.713 indicates the value of the synergy variable will remain at 3.713 if all independent variables are zero.
- Innovation has a coefficient value of 0.152 , meaning that if the value of this variable is increased one unit then it will increase the value of the synergy variable of $0.152(15.2 \%)$ with the assumption that other variables are fixed.

- Information technology has a coefficient value of 0.133 , meaning that if the value of this variable is increased one unit then it will increase the value of the synergy variable of $0.133(13.3 \%)$ with the assumption that other variables are fixed.

- MSMES development has a coefficient value of 0.564 , meaning that if the value of this variable is increased one unit then it will increase the value of the synergy variable of $0.564(56.4 \%)$ with the assumption that other variables are fixed.

Table 4. Results of Multiple Linear Regression Analysis Equation Model II

\begin{tabular}{lrrr}
\hline \multicolumn{1}{c}{ Model } & $\mathrm{B}$ & $\mathrm{t}$ & $\mathrm{S}$ Sig \\
\hline (Constant) & 3.713 & 2.785 & .006 \\
Innovation & .152 & 4.050 & .000 \\
IT & .133 & 4.024 & .000 \\
MSMES & & & \\
& .564 & 11.386 & .000 \\
\hline
\end{tabular}

\section{F-test results}

F test is used to see the effect of innovation, information technology and MSMEs development simultaneously on synergy. Based on table 5 , it can be concluded that the F test results show a significant value of 0.000 is smaller than 0.05 . The results of this $\mathrm{F}$ test indicate that the independent variables simultaneously have a significant impact on the dependent variable that is synergy.

\begin{tabular}{crcc}
\multicolumn{5}{c}{ Table 5. F-test results } \\
\hline Model & \multicolumn{1}{c}{ df } & F & Sig. \\
\hline $\begin{array}{c}\text { Regression } \\
\text { Residual }\end{array}$ & 3 & 121.191 & $.000^{\mathrm{a}}$ \\
& 296 & & \\
\hline
\end{tabular}

\section{D. $t$-test results}

Based on Table 6, the results of the regression test analysis stated that among innovation, information technology and MSMEs development have a partially significant impact (individual) on the synergy of MSMEs with the Government. Innovation has significant significance t-test result of $0.000<$ 0.05 , means that innovation partially significant effect on synergy. IT has a significance value of $0.000<0.05$, means that it partially has significant effect on synergy. The development of MSMEs has a significance value of $0.000<$ 0.05 , means that the development of MSMEs partially has a significant effect on the synergy. 
Table 6. t-test results

\begin{tabular}{lrrr}
\hline \multicolumn{1}{r}{ Model } & \multicolumn{1}{r}{ B } & \multicolumn{1}{c}{$\mathrm{t}$} & \multicolumn{1}{c}{ Sig } \\
\hline (Constant) & 3.713 & 2.785 & .006 \\
Innovation & .152 & 4.050 & .000 \\
IT & .133 & 4.024 & .000 \\
MSMEs & .564 & 11.386 & .000 \\
\hline
\end{tabular}

\section{E. Coefficient of Determination Test}

The coefficient of determination $\left(\mathrm{R}^{2}\right)$ essentially measures how far the model's ability to explain the variation of the dependent variable. Range value is 0 to 1 , if the value of $R^{2}$ is small means the ability of independent variables in explaining the variation of dependent variable is very limited, otherwise if $\mathrm{R}^{2}$ approaches value 1 means the ability of independent variables in explaining dependent variable. Based on Table 7, the magnitude of $\mathrm{R}^{2}$ is 0.551 which means $0.551(55.1 \%)$ independent variable able to describe synergicity. While the rest of $44.9 \%$ described or explained by other variables that are not included in the research model.

Table 7. Coefficient of Determination Test

\begin{tabular}{crrr}
\hline Model & R & R Square & $\begin{array}{c}\text { Adjusted R } \\
\text { Square }\end{array}$ \\
\hline 1 & $.742^{\circ}$ & .551 & .547 \\
\hline
\end{tabular}

\section{F. Path Analysis Channel 1 \& 2 With Innovation Variable}

Path analysis is used to examine the effect of mediation on a research model through intervening variables. Intervention variable in this research is development of MSMEs. The following is the result of path analysis in this research. Based on SPSS 16, the output results in Table 8, the standardized value of innovation beta in equation $I$ is 0.379 and a significant value of 0.000 which means innovation significantly influences the development of MSMEs. The value of standardized coefficient beta 0.308 is the path or path value $\mathrm{p}_{2}$. At SPSS 16 output equation II standardized beta value for innovation is 0.180 and MSE development is 0.542 . The value of standardized beta of innovation of 0.180 is the $p_{1}$ path value and the standardized value of the UMKM development of 0.542 is the $\mathrm{p}_{3}$ point value. The value of $\mathrm{e}_{1}=$ 0.670 and the value of $\mathrm{e}_{2}=0.258$

Table 8. Path Analysis Innovation Channel I

\begin{tabular}{ccccc}
\hline \multicolumn{5}{c}{$\mathrm{R}$} \\
Model & Square & Beta & $\mathrm{t}$ & Sig. \\
\hline Innovation & .330 & .379 & 7.662 & 0.000 \\
\hline
\end{tabular}

The result of path analysis shows that the direct effect $\left(\mathrm{p}_{1}\right)$ is $0.180(18 \%)$ while the indirect effect is calculated by multiplying the indirect coefficient of $0.379 \times 0.542=0.205$ $(20.5 \%)$. The indirect effect of innovation on synergy is greater than its direct effect $(0.205>0.180)$.

Table 9. Path Analysis Innovation Channel II

\begin{tabular}{ccccc}
\hline \multicolumn{5}{c}{$\mathrm{R}$} \\
Model & Square & Beta & \multicolumn{1}{c}{$\mathrm{t}$} & Sig. \\
\hline & & & & \\
Innovation & .742 & .180 & 4.050 & .000 \\
MSMEs & & .542 & 11.386 & .000 \\
\hline
\end{tabular}

\section{G. Analysis of Innovation Path Result of Equation I \& 2}

Based on SPSS output results in Table 10, the standardized value of information technology beta in Channel I is 0.337 and a significant value of 0.000 which means information technology significantly influences the development of MSMEs. The value of standardized coefficient beta 0.337 is the path or path value $\mathrm{p}_{2}$.

Table 10. Analysis of Innovation Path Result of Equation I $\mathrm{R}$

\begin{tabular}{crrrr} 
Model & Square & Beta & $\mathrm{t}$ & Sig. \\
\hline Innovation & .330 & .337 & 6.801 & 0.000 \\
\hline
\end{tabular}

At the output of SPSS 16 equation II the standardized beta value for information technology is 0.176 and the development of MSMEs is 0.542 . The standardized beta value of information technology of 0.176 is the $p 1$ path value and the standardized beta value of the MSMEs development of 0.542 is the $\mathrm{p} 3$ point value. The value of $\mathrm{e} 1=0.670$ and the value of $\mathrm{e} 2=0.258$

Table 11. Analysis of Innovation Path Result of Equation II

\begin{tabular}{crrrr}
\hline \multicolumn{5}{c}{$\mathrm{R}$} \\
Model & Square & Beta & \multicolumn{1}{c}{$\mathrm{t}$} & Sig. \\
\hline IT & & & & \\
MSMEs & .742 & .176 & 4.024 & .000 \\
& & .542 & 11.386 & .000 \\
\hline
\end{tabular}

\section{H. Discussion}

The empowerment of MSMEs in the midst of globalization and high competitiveness. MSMEs have to be able to face global challenges such as improving product and service innovation, human resource and technology development. Bases on the research results that innovation and information technology have an effect on the development of MSMEs. Information technology also has a significant influence on the development of MSMEs in North Sumatra. Innovation, 
information technology, and MSMEs development have an effect on synergy. The product launch and presentation to the market is a crucial moment of the whole development process. This is an important phase to reach success in sales. Products equilibrium illustrates a problem, every product exists in the market always has its own value.

Most of 99\% MSMEs in Indonesia are micro enterprises in the informal sector and generally use local raw materials with local markets. The Synergy between MSMEs and government is needed. If MSMEs and government elements are running independently of each other without any synergy, it may be that an element will only negate the other elements. However, if it can be done together, then both MSMEs and the Government will be mutually helped by the existence of synergicity. The government of course is expected to be a policy maker that can provide facilities for MSMEs to develop their business. Internet advertising started in 1994 in the form of banner advertisement that can be developed. Online advertising frequently involves both MSMEs, who integrates advertisements into its online content, and an advertiser who provides the advertisements to be displayed on the customer's need.

To improve its competitiveness, MSMEs must innovate continuously. To determine the effect of innovation on the development of MSMEs, a measurement should be done. In facing the AEC, the need to prepare some regulations that can protect the products of MSMEs so as not to lose competitiveness from foreign products, and MSMEs as well as the government must also ensure the quality of local products capable of competitive, so it is worth entering the international market. It is expected that there will be incentives in the form of conditional fresh money from the government in order to motivate MSMEs to continue to expand their business.

Innovation is taking place everywhere through new and emerging technologies changing the way we think, live, breathe, travel, and do shopping to name a few areas. The government must intervene to ensure the region is able to optimize its potential to provide innovation and IT affects the synergy through the development of MSMEs in North Sumatra.

The ability to quantify this value is related to $\mathrm{R} \& \mathrm{D}$. Innovation and IT affect the synergy through the development of MSMEs in North Sumatra. The growing MSMEs in an area will certainly have a positive impact for the region itself. MSMEs is a regional asset, and the government itself has also known the importance of MSMEs for a region. With the development of MSMEs, local revenue will also increase, with the MSMEs factors of poverty can also be reduced, in addition to the potentials that exist in the region can also be more managed by the MSMEs.

\section{CONCLUSIONS AND RECOMMENDATIONS}

\section{A. Conclusions}

Based on the data analysis and discussion of the results of the analysis, the following conclusions such as :

- Innovation and information technology partially significant effect on the development of MSMEs in North Sumatra.

- Innovation, IT and the development of MSMEs affect the synergy of MSMEs with the Province Government of North Sumatra.

- Innovation and IT can have a significant effect on the synergy of MSMEs with the government through the development of MSMEs in North Sumatra.

\section{B. Recommendations}

Based on the results of the discussion and the conclusions of this study, it is advisable:

- With the synergy between the government and MSMEs, the two elements will improve each other's performance. It is expected that the Provincial Government of North Sumatera should be able to keep monitoring and participate in the development of MSMEs especially in North Sumatra.

- It is also expected that the Provincial Government of North Sumatra in order to make policies that will help MSMEs in order to compete with foreign products in the AEC.

- The government can also assist MSMEs in terms of labor and capital. That is by providing socialization, training and funding for MSMEs in order for MSMEs in North Sumatra to grow and can survive in the AEC.

\section{REFERENCES}

[1] Sudaryanto., 2011. The Need For Ict-Education For Manager Or Agribusinessman To Increasing Farm Income: Study Of Factor Influences On Computer Adoption In East Java Farm Agribusiness International Journal Of Education And Development Edict, pp. 18 WEF., 2011. 2world Economic Forum (Wef). 2011 Http://Www.Bappenas.Go.Idhttp://Www.Bappenas.Go.Id/Blog/W pcontent/Uploads/2012/10/2_Peringkat-Daya-Saing-Indonesia2011-Hary-Dralat

[3] Widihandayani., Rachel, 2011. Pengaruh Inovasi Terhadap Daya Saing Pada Umkm. JurnaUniversitas Diponegoro.pp. 1-7

[4] Torkkeli., Mention and Ferreira, 20154. The Power Of Technology: A Fact Or Fiction For Majority? Journal Of Innovation Management Jim. pp.1-3

[5] Marques. 2014. 5closed Versus Open Innovation: Evolution Or Combination? International Journal Of Business And Management; Vol. 9, No. 3. pp. 196-203

[6] Zaumane. 2017. 6the Internal Communication Crisis And Its Impact On An Organization's Performance Journal Of Business Management. pp.1224-33

[7] Townsend. 2010.7innovation And The Value Of Failure International Journal Of Management And Marketing Research Volume 3 pp. $75-84$ 
[8] Cimatti., Campana. 2016. Modern Industrial Product Development And Organizational Impact International Journal Of Organizational Innovation. pp. 8-17

[9] Yang., Yuan. 2014. The Innovation Management Research Based On Brand Strategy Of Haier Group International Journal Of Managerial Studies And Research (Ijmsr) Volume 2, Issue 10. pp. $142-147$

[10] Dencheva. 2009. Effectiveness Of Internet Advertisement 3rd Central European Conference In Regional Science - Cers. pp. 988994

[11] Anusha. 2016. Effectiveness Of Online Advertising International Journal Of Research Granthaalayah. pp. 14-21 